\title{
Geofilum rubicundum gen. nov., sp. nov., isolated from deep subseafloor sediment
}

\author{
Masayuki Miyazaki, ${ }_{1}$ Osamu Koide, ${ }^{2}$ Tohru Kobayashi, ${ }^{2}$ Kozue Mori, ${ }^{3}$ \\ Shigeru Shimamura, ${ }^{1}$ Takuro Nunoura, ${ }^{1}$ Hiroyuki Imachi, ${ }^{1}$ Fumio Inagaki, ${ }^{4}$ \\ Takahiko Nagahama, ${ }^{2}$ Yuichi Nogi, ${ }^{2}$ Shigeru Deguchi ${ }^{2}$ and Ken Takai ${ }^{1}$

\begin{abstract}
${ }^{1}$ Subsurface Geobiology Advanced Research (SUGAR) project, Japan Agency for Marine-Earth Science and Technology (JAMSTEC), 2-15 Natsushima-cho, Yokosuka 237-0061, Japan

${ }^{2}$ Soft Matter and Extremophiles Research Team, Japan Agency for Marine-Earth Science and Technology (JAMSTEC), 2-15 Natsushima-cho, Yokosuka 237-0061, Japan

${ }^{3}$ Marine Bioresource Exploration Research Team and Institute of Biogeosciences (BioGeos), Japan Agency for Marine-Earth Science and Technology (JAMSTEC), 2-15 Natsushima-cho, Yokosuka 237-0061, Japan

${ }^{4}$ Geomicrobiology Group, Kochi Institute for Core Sample Research, Japan Agency for MarineEarth Science and Technology (JAMSTEC), 2-15 Natsushima-cho, Yokosuka 237-0061, Japan
\end{abstract}

Correspondence Masayuki Miyazaki miyazakim@jamstec.go.jp
The family Marinilabiliaceae within the order Bacteroidales was proposed by Ludwig et al. (2008). At the time of writing, this family includes three genera, namely Marinilabilia, Alkaliflexus and Anaerophaga. Marinilabilia salmonicolor was originally described as a species of the genus Cytophaga by Veldkamp (1961) to accommodate a novel, facultatively anaerobic, agar-degrading bacterium isolated from marine sediment. Based on phylogenetic affiliation as well as physiological and chemotaxonomic characteristics, this bacterium was transferred to a novel genus, Marinilabilia, by Nakagawa \& Yamasato (1996). The

\section{Abbreviations: ML, maximum-likelihood; NJ, neighbour-joining.}

The GenBank/EMBL/DDBJ accession number for the 16S rRNA gene sequence of strain JAM-BA0501 ${ }^{\top}$ is AB362265.

One supplementary table and three supplementary figures are available with the online version of this paper. genus Alkaliflexus was described and proposed by Zhilina et al. (2004) for a novel, anaerobic, low- $\mathrm{O}_{2}$-tolerant, alkaliphilic bacterium isolated from soda lake sediments. The genus Anaerophaga was erected to accommodate a novel, strictly anaerobic, thermophilic bacterium isolated from an oilfield (Denger et al., 2002). All recognized members of the family are facultatively or strictly anaerobic heterotrophs.

A diversity of aerobic heterotrophic bacteria were isolated from subseafloor sediment samples cored from offshore of the Shimokita Peninsula, Japan, by the deep-earth research drilling vessel Chikyu in 2006 from multiple sample depths down to $365 \mathrm{~m}$ below the seafloor (drilling site C9001C, $41^{\circ} 10.6380^{\prime} \mathrm{N} 142^{\circ} 12.081^{\prime}$ E: see Kobayashi et al., 2008). The depth of overlying seawater at Site C9001C is $1180 \mathrm{~m}$. Preliminary phylogenetic analysis based on 16S rRNA gene sequences showed that several isolates might represent 
novel phylotypes within the order Bacteroidales (Kobayashi et al., 2008).

In this study, we characterized the taxonomic properties of one of these strains, designated JAM-BA0501 ${ }^{\mathrm{T}}$, isolated from a deep sediment core sample at $247 \mathrm{~m}$ below the seafloor, which appeared to represent a novel, facultatively anaerobic member of a new genus within the family Marinilabiliaceae. Strain JAM-BA0501 ${ }^{\mathrm{T}}$ was purified by colony-isolation on marine agar 2216 (MA; Difco) at $30{ }^{\circ} \mathrm{C}$. The isolate was maintained on MA plates or in marine broth 2216 (MB; Difco) at $30{ }^{\circ} \mathrm{C}$ and stored at $-80{ }^{\circ} \mathrm{C}$ in $15 \%(\mathrm{v} / \mathrm{v})$ glycerol.

Cells were observed routinely by using an Olympus BX51 microscope. Transmission electron microscopy of negatively stained cells and sections of cells was conducted with a JEM-1210 (JEOL) as described by Nogi et al. (1998). Cells of strain JAM-BA0501 ${ }^{\mathrm{T}}$ in the mid-exponential phase of growth in $\mathrm{MA}$ at $30{ }^{\circ} \mathrm{C}$ were used for electron microscopic observations. Cells were filamentous, approx. 0.2-0.4 $\mu \mathrm{m}$ wide and 4.0-22.0 $\mu \mathrm{m}$ long (Fig. 1) and with both outer and inner membrane structures (Fig. 1b). Many fimbriaelike structures were observed on the cell surface (Fig. 1a). Strain JAM-BA0501 ${ }^{\mathrm{T}}$ was motile on solid medium by means of gliding.

Unless otherwise noted, physiological properties of strain JAM-BA $0501^{\mathrm{T}}$ were examined by using YPA medium containing $0.5 \%(\mathrm{w} / \mathrm{v})$ yeast extract (Difco) and $0.5 \%$ $(\mathrm{w} / \mathrm{v})$ peptone (Difco) based on artificial seawater (ASW: consisting of $2.75 \% \mathrm{NaCl}, 0.07 \% \mathrm{KCl}, 0.54 \% \mathrm{MgCl}_{2} .6 \mathrm{H}_{2} \mathrm{O}$, $0.68 \% \mathrm{MgSO}_{4} \cdot 7 \mathrm{H}_{2} \mathrm{O}, 0.14 \% \mathrm{CaCl}_{2} \cdot 2 \mathrm{H}_{2} \mathrm{O}$ and $0.02 \%$ $\mathrm{NaHCO}_{3}$ ), modified slightly from that given by Nogi \& Kato (1999), or MB. The effect of temperature, $\mathrm{NaCl}$ concentration and $\mathrm{pH}$ on cell growth was determined by examining the time course of optical density (temperature gradient incubator with a bio-photorecorder, model TVS126MA; Advantec). Growth at $10-45{ }^{\circ} \mathrm{C}$ was tested in $\mathrm{MB}$; the optimal growth temperature was $33{ }^{\circ} \mathrm{C}$. Cell growth was observed at 10 and $35{ }^{\circ} \mathrm{C}$, but not above $38{ }^{\circ} \mathrm{C}$ (see Fig. S1a available in IJSEM Online). The effect of $\mathrm{NaCl}$ concentration on growth was examined with YPA medium in the presence of $0-7 \%(\mathrm{w} / \mathrm{v}) \mathrm{NaCl}$. Optimal growth occurred with $1 \% \mathrm{NaCl}$. Cell growth was observed in the presence of 0.5 and $6 \% \mathrm{NaCl}$, but not in the absence of $\mathrm{NaCl}$ or in the presence of $>7 \% \mathrm{NaCl}$ (Fig. S1b). The optimal $\mathrm{pH}$ and $\mathrm{pH}$ range for cell growth were determined in YPA buffered with $10 \mathrm{mM}$ Tris to a $\mathrm{pH}$ of $6.4,6.9,7.3,7.8,8.3$, $8.8,9.3$ or 9.8 at room temperature (approx. $25^{\circ} \mathrm{C}$ ). Optimal growth occurred at $\mathrm{pH}$ 7.3-8.3. Cell growth was observed at $\mathrm{pH} 6.9$ and 9.3, but not at $\mathrm{pH} 6.4$ or at greater than $\mathrm{pH} 9.8$ (Fig. S1c).

To determine the utilization of organic substrates for cell growth, each of the following substrates was added to ASW supplemented with $0.1 \%$ (w/v) $\mathrm{NH}_{4} \mathrm{Cl}$ and $10 \mathrm{mM}$ Tris $(\mathrm{pH} 8.0)$ in the presence or absence of $0.01 \%(\mathrm{w} / \mathrm{v})$ yeast extract: L-arabinose, cellobiose, D-fructose, D-galactose, D-glucose, glycerol, myo-inositol, lactose, maltose, Dmannitol, D-mannose, raffinose, L-rhamnose, D-sorbitol, L-sorbose, sucrose, trehalose, xylose (all at $1.0 \%, \mathrm{w} / \mathrm{v}$ ), Lalanine, $\mathrm{L}$-arginine, $\mathrm{L}$-asparagine, $\mathrm{L}$-aspartic acid, L-cysteine, L-glutamic acid, L-glutamine, glycine, L-histidine, L-isoleucine, L-leucine, L-lysine, L-methionine, L-phenylalanine, L-proline, L-serine, L-threonine, L-tryptophan, L-tyrosine or L-valine (all at $0.5 \%, \mathrm{w} / \mathrm{v}$ ). We also tested cell growth in ASW containing $1.0,0.1$ or $0.01 \%(\mathrm{w} / \mathrm{v})$ yeast extract as the sole substrate. The isolate was able to grow in ASW containing 1.0 and $0.1 \%(\mathrm{w} / \mathrm{v})$ yeast extract solely, but no cell growth was observed in ASW medium containing $0.01 \%(\mathrm{w} / \mathrm{v})$ yeast extract. In addition, strain JAMBA0501 ${ }^{\mathrm{T}}$ did not grow on the sugars and amino acids that we tested as sole energy and carbon sources. However, when these substrates were supplemented with ASW containing $0.01 \%(\mathrm{w} / \mathrm{v})$ yeast extract, the isolate was able to grow with cellobiose, D-fructose, D-galactose, lactose, Dmannose, L-rhamnose, trehalose and xylose. These results indicated that strain JAM-BA0501 ${ }^{\mathrm{T}}$ utilized such sugars as energy and carbon source.

Oxidase activity was determined by spreading cell pellets on oxidase test paper (Nissui Pharmaceutical). Catalase activity was determined based on $\mathrm{O}_{2}$-bubble production in $3 \%(\mathrm{v} / \mathrm{v}) \quad \mathrm{H}_{2} \mathrm{O}_{2}$ solution. Agarase, amylase, cellulase, chitinase, gelatinase, lipase (tri- $n$-butyrin), protease and xylanase activities were tested on MA plates by using each substrate at $1 \%(\mathrm{w} / \mathrm{v})$. DNase activity was assessed with DNase Test Agar (Difco). Hydrolysis of aesculin, ONPG,
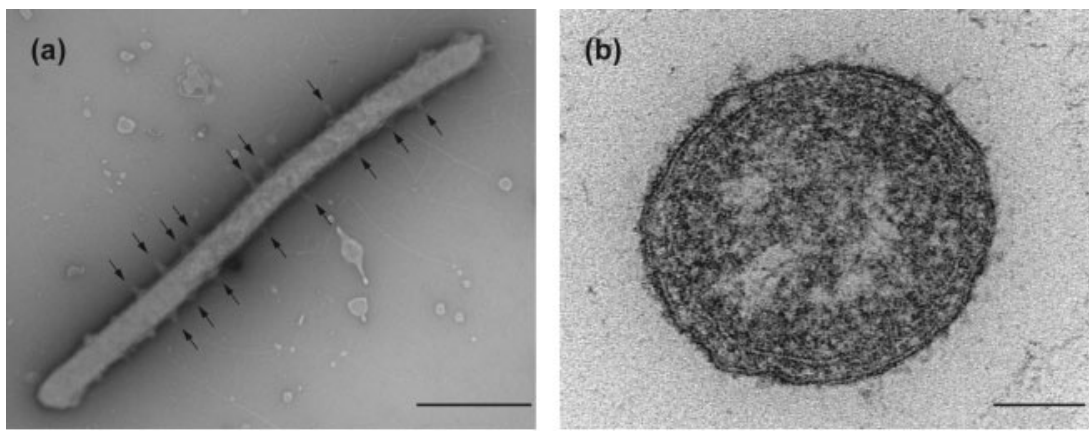

Fig. 1. Transmission electron micrograph of a negatively stained cell (a) and thin section of a cell (b) of strain JAM-BA0501 ${ }^{\top}$. Fimbriae-like structures are indicated by arrows (a). Bars, $1.0 \mu \mathrm{m}(\mathrm{a})$ and $100 \mathrm{~nm}$ (b). 
and Tweens 20, 40 and 80 was studied as described by Barrow \& Feltham (1993). Based on these enzyme assays of strain JAM-BA0501 ${ }^{\mathrm{T}}$, the isolate was found to be positive only for amylase and protease activities and was able to hydrolyse aesculin, ONPG, Tween 20 and Tween 40.

Antibiotic susceptibility was tested in MB. Strain JAMBA0501 ${ }^{\mathrm{T}}$ was susceptible to (per millilitre) ampicillin $(10 \mu \mathrm{g})$, chloramphenicol $(30 \mu \mathrm{g})$, erythromycin $(15 \mu \mathrm{g})$, penicillin $(10 \mu \mathrm{U})$, rifampicin $(5 \mu \mathrm{g})$, tetracycline $(30 \mu \mathrm{g})$ and vancomycin $(30 \mu \mathrm{g})$, but resistant to gentamicin $(10 \mu \mathrm{g})$, kanamycin $(30 \mu \mathrm{g})$, nalidixic acid $(30 \mu \mathrm{g})$ and neomycin $(30 \mu \mathrm{g})$.

Nitrate and nitrite reduction were determined as described by Barrow \& Feltham (1993). Hydrogen sulfide production from thiosulfate and the production of indole were assessed by using sulfide indole motility agar (Nissui Pharmaceutical) stabs prepared with ASW instead of water. Strain JAM-BA0501 ${ }^{\mathrm{T}}$ reduced nitrate and nitrite, but did not produce hydrogen sulfide or indole.

Anaerobic growth of strain JAM-BA0501 ${ }^{\mathrm{T}}$ was tested with YPA medium in the presence or absence of $0.1 \%(\mathrm{w} / \mathrm{v})$ $\mathrm{KNO}_{3}$ under a $100 \% \mathrm{~N}_{2}$ atmosphere $(100 \mathrm{kPa})$. The isolate grew with YPA medium in the presence of nitrate but did not show fermentative growth. This indicated that strain JAM-BA0501 ${ }^{\mathrm{T}}$ was a facultative anaerobe, growing via $\mathrm{O}_{2}-$ respiration and nitrate-reduction under aerobic and anaerobic conditions, respectively. The general physiological characteristics of strain JAM-BA0501 ${ }^{\mathrm{T}}$ are summarized in Table 1 or are given in the genus and species descriptions below.

The absorption spectrum of pigment extracted with $3 \mathrm{ml}$ acetone/methanol $(7: 2)(\mathrm{v} / \mathrm{v})$ from harvested cells ( $1 \mathrm{~g}$ wet pellet) was determined at $300-700 \mathrm{~nm}$ with a Hitachi U2000 spectrophotometer (Miyazaki et al., 2010). Cells of strain JAM-BA0501 ${ }^{\mathrm{T}}$ produced salmon pink pigments with maximum absorbance at $480 \mathrm{~nm}$ (Table 1).

Cells of strain JAM-BA0501 ${ }^{\mathrm{T}}$ at the late-exponential phase of growth in $\mathrm{MB}$ at $30{ }^{\circ} \mathrm{C}$ were used for characterization of isoprenoid quinones, cellular fatty acids and polar lipids. Isoprenoid quinones were extracted with chloroform/ methanol (2:1) (v/v) from lyophilized cells (200 mg) and purified by TLC. The purified isoprenoid quinones were analysed by using HPLC (Komagata \& Suzuki, 1987). The major isoprenoid quinone of strain JAMBA0501 ${ }^{\mathrm{T}}$ was menaquinone MK-7. The fatty acids of strain JAM-BA0501 ${ }^{\mathrm{T}}$ and related genera were obtained from cells by saponification, methylation and extraction according to the Sherlock Microbial Identification System (MIDI, 1999). Fatty acid compositions were determined by using a Finnigan TRACE DSQ GC-MS system (Thermo Fisher Scientific) equipped with a DB-5 column (J\&W Scientific) under a helium flow of $1.5 \mathrm{ml} \mathrm{min}{ }^{-1}$ and an oven temperature programme increasing from $140{ }^{\circ} \mathrm{C}(5 \mathrm{~min})$ to $280{ }^{\circ} \mathrm{C}(5 \mathrm{~min})$ at $4{ }^{\circ} \mathrm{C} \mathrm{min}{ }^{-1}$. The major fatty acids were iso- $\mathrm{C}_{15: 0}$ and anteiso- $\mathrm{C}_{15: 0}$
(Table S1). The polar lipids of strain JAM-BA0501 ${ }^{\mathrm{T}}$ were extracted according to the procedures described by Minnikin et al. (1984) and were identified by using two-dimensional TLC followed by spraying with the appropriate detection reagents (Minnikin et al., 1984; Komagata \& Suzuki, 1987). Polar lipid analysis revealed the presence of phosphatidylethanolamine, diphosphatidylglycerol and an unknown glycolipid (Fig. S2).

Genomic DNA of the isolate was extracted and purified by using the phenol extraction method (Saito \& Miura, 1963). The DNA G + C content was determined by reversed-phase HPLC (Tamaoka \& Komagata, 1984). The almost fulllength $16 \mathrm{~S}$ rRNA gene sequence $(\sim 1440 \mathrm{bp})$ of strain JAM-BA0501 ${ }^{\mathrm{T}}$ was determined by direct sequencing of PCR-amplified DNA as described previously (Miyazaki et al., 2008). The sequence was aligned with a subset of $16 \mathrm{~S}$ rRNA gene sequences obtained from public databases via the FASTAligner utility of ARB software (Ludwig et al., 2004). Phylogenetic trees were reconstructed with the neighbour-joining (NJ) and maximum-likelihood (ML) methods by using PaUp 4.0 beta 10 (Swofford, 1998). The NJ tree (Saitou \& Nei, 1987) was reconstructed by using the parameters of the Jukes-Cantor model distance. The ML tree (Felsenstein, 1981) was drawn by using the default starting parameters (NJ with a Jukes-Cantor model of evolution). Bootstrap confidence of branching was calculated based on 1000 and 250 replications for the NJ and ML trees, respectively.

The phylogenetic tree inferred from the NJ method is shown in Fig. 2 (a global tree is available as Fig. S3). The result of phylogenetic analysis indicated that strain JAM$\mathrm{BA} 0501^{\mathrm{T}}$ was affiliated to the family Marinilabiliaceae within the order Bacteroidales and was distantly related to Alkaliflexus imshenetskii Z-7010 ${ }^{\mathrm{T}}$ (91.1\% 16S rRNA gene sequence similarity), Marinilabilia salmonicolor ATCC $19041^{\mathrm{T}}(86.2 \%)$ and Anaerophaga thermohalophila Fru22 ${ }^{\mathrm{T}}$ $(89.3 \%)$.

Although strain JAM-BA0501 ${ }^{\mathrm{T}}$ had morphological and physiological properties similar to those of members of the order Bacteroidales, several taxonomic features, such as non-spherical cell formation and major fatty acid composition, differ from those of related genera in the family Marinilabiliaceae and even other genera within the order Bacteroidales (Table 1). In addition, the NJ phylogenetic tree indicates that strain JAM-BA0501 ${ }^{\mathrm{T}}$ is related most closely to Alkaliflexus imshenetskii Z-7010 ${ }^{\mathrm{T}}$ (Fig. 2). Although the two strains share many taxonomic properties (Table 1), Alkaliflexus imshenetskii $\mathrm{Z}-7010^{\mathrm{T}}$ is not able to grow aerobically or to reduce nitrate (Table 1 ). They also differ in utilization pattern of carbohydrates and 3-hydroxy fatty acid composition. On the basis of these phenotypic and phylogenetic characteristics, strain JAM$\mathrm{BA} 0501^{\mathrm{T}}$ is considered to represent a novel species of a new genus within the family Marinilabiliaceae, for which we propose the name Geofilum rubicundum gen. nov., sp. nov. 
Table 1. Differential characteristics between strain JAM-BA0501 ${ }^{\top}$ and related type species of the family Marinilabiliaceae

Strains: 1, JAM-BA0501 $1^{\mathrm{T}} ; 2$, Alkaliflexus imshenetskii Z-7010 ${ }^{\mathrm{T}} ; 3$, Marinilabilia salmonicolor ATCC $19041^{\mathrm{T}} ; 4$, Anaerophaga thermohalophila Fru22 $2^{\mathrm{T}} ; 5$, Cytophaga fermentans ATCC $19072^{\mathrm{T}}$, 6, Marinifilum fragile JC2469 ${ }^{\mathrm{T}}$. Data for reference type strains are from Bachmann (1955), Denger et al. (2002), Holt et al. (1994), Na et al. (2009), Suzuki et al. (1999), Veldkamp (1961) and Zhilina et al. (2004) except where indicated otherwise. ND, No data.

\begin{tabular}{|c|c|c|c|c|c|c|}
\hline Characteristic & 1 & 2 & 3 & 4 & 5 & 6 \\
\hline Origin & Subsurface & Soda lake & Marine & Oilfield & Marine & Marine \\
\hline Colony colour & Salmon pink & Pink & Yellow to salmon pink & Orange-red & Bright yellow & $\begin{array}{c}\text { Ivory or brownish } \\
\text { ivory }\end{array}$ \\
\hline \multicolumn{7}{|l|}{ Cell form } \\
\hline Size & $0.2-0.4 \times 4.0-22.0$ & $0.25-0.4 \times 4-10$ & $0.3-0.5 \times 2-50$ & $0.3 \times 4-8$ & $0.5-0.7 \times 2-10$ & $0.5 \times 0.3-3.8$ \\
\hline Motility & Gliding & Gliding & Gliding & Not observed & Gliding & Flagella-like \\
\hline Coccoid forms & - & + & + & - & ND & ND \\
\hline \multicolumn{7}{|l|}{ Growth ( ${ }^{\circ} \mathrm{C}$, after 1 week $)$} \\
\hline Optimum & 33 & 35 & $28-37$ & 55 & 30 & 33.8 \\
\hline Range & $10-36$ & $10-45$ & ND & $37-55$ & ND & $20-37.4$ \\
\hline \multicolumn{7}{|l|}{$\mathrm{NaCl}(\%, 1$ week $)$} \\
\hline Optimum & 1.0 & 2.0 & ND & $2.0-6.0$ & ND & 3 \\
\hline Range & $0.5-6.0$ & $0.08-5.3$ & $1.0-3.0$ & $2.0-12.0$ & $<3.0$ & $1-7$ \\
\hline \multicolumn{7}{|l|}{$\mathrm{pH}$} \\
\hline Optimum & $7.3-8.3$ & 8.5 & $7.0-7.5$ & 6.8 & ND & 7 \\
\hline Range & $6.9-9.3$ & $7.2-10.2$ & ND & ND & ND & $6-8$ \\
\hline $\mathrm{O}_{2}$ metabolism & Facultatively anaerobic & $\begin{array}{c}\text { Anaerobic; low } \mathrm{O}_{2} \\
\text { tolerance }\end{array}$ & Facultatively anaerobic & Strictly anaerobic & Facultatively anaerobic & Facultatively anaerobic \\
\hline Catalase & + & + & + & - & + & - \\
\hline Oxidase & - & ND & ND & - & ND & + \\
\hline Agarase & - & - & $\mathrm{ND}$ & - & + & ND \\
\hline Gelatinase & + & - & + & ND & ND & + \\
\hline Xylanase & - & + & + & + & + & $\mathrm{ND}$ \\
\hline Nitrate reduction & + & - & + & $\mathrm{ND}$ & - & + \\
\hline Major fatty acid(s) $\dagger$ & i15: 0, a15:0 & $\mathrm{i} 15: 0$, a $15: 0^{*}$ & $\mathrm{i} 13: 0, \mathrm{i} 15: 0$, a15:0* & $\mathrm{i} 15: 0$, a15:0 & ND & i15: 0 \\
\hline $\begin{array}{l}\text { 3-Hydroxylated cellular fatty } \\
\text { acids }\end{array}$ & $\begin{array}{c}\mathrm{i} 15: 0, \text { a } 15: 0,16: 0, \mathrm{i} 16: 0 \\
\text { i1 } 17: 0, \text { a } 17: 0\end{array}$ & $\begin{array}{c}\mathrm{i} 15: 0,16: 0, \mathrm{i} 17: 0, \\
\text { a17: } 0^{*}\end{array}$ & $\mathrm{i} 15: 0$, a $15: 0, \mathrm{i} 16: 0, \mathrm{i} 17: 0^{*}$ & $\begin{array}{c}15: 0,16: 0, \mathrm{i} 16: 0 \\
\mathrm{i} 17: 0\end{array}$ & ND & $\mathrm{i} 15: 0, \mathrm{i} 17: 0$ \\
\hline $\begin{array}{l}\text { Absorption maximum(a) of } \\
\text { pigments }(\mathrm{nm})\end{array}$ & 480 & 485 & $\mathrm{ND}$ & 488,518 & ND & ND \\
\hline DNA G $+C$ content $(\mathrm{mol} \%)$ & 42.9 & 44.3 & 37 & 41.8 & 39 & 45 \\
\hline
\end{tabular}

${ }^{\star}$ Data from the present study.

$\dagger \mathrm{i}$, Iso branched; a, anteiso branched. 


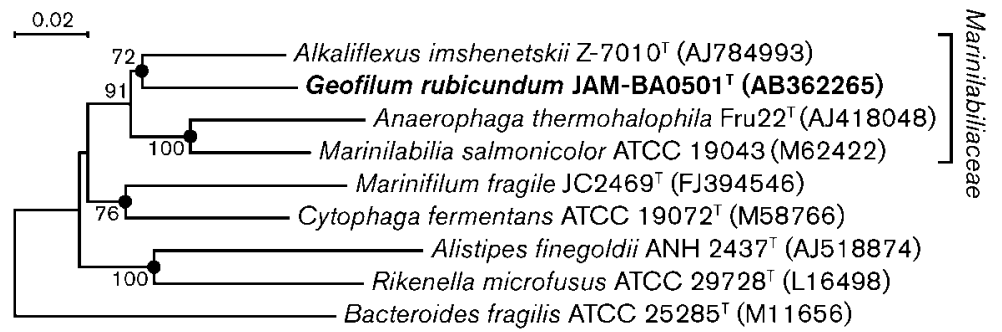

Fig. 2. Neighbour-joining phylogenetic tree based on 16S rRNA gene sequences of representative genera and species within the family Marinilabiliaceae. The tree was rooted with Bacteroides fragilis ATCC $25285^{\top}$. Bootstrap values (percentages of 1000 replicates) are given at branch points; only values $>50 \%$ are shown. Solid circles indicate that the corresponding nodes (groups) were also recovered by using the $\mathrm{ML}$ method at $>50 \%$ support (250 replicates). GenBank accession numbers of $16 \mathrm{~S}$ rRNA gene sequences are given in parentheses. Bar, 0.02 nt substitutions per site. An expanded version of this tree is available as Fig. S3.

\section{Description of Geofilum gen. nov.}

Geophilum (Ge.o.fi'lum. Gr. n. ge the earth; L. neut. n. filum a thread; N.L. neut. n. Geophilum a thread from the earth).

Cells are Gram-negative, filamentous and non-sporeforming. Facultatively anaerobic and organoheterotrophic. Catalase-positive. Motile by means of gliding. Mesophilic. $\mathrm{NaCl}$ is required for growth. The major respiratory quinone is MK-7. The cellular fatty acid profile is dominated by branched saturated components. The polar lipids are phosphatidylethanolamine, diphosphatidylglycerol and an unknown glycolipid. The genus is affiliated to the family Marinilabiliaceae. The type species is Geofilum rubicundum.

\section{Description of Geofilum rubicundum sp. nov.}

Geofilum rubicundum (ru.bi.cun'dum. L. neut. adj. rubicundum red, ruddy).

Displays the following properties in addition to those given in the genus description. Cell width ranges from 0.2 to $0.4 \mu \mathrm{m}$, and cell length ranges from 4.0 to $22.0 \mu \mathrm{m}$. Cells possess numerous fimbriae but no flagellum. Colonies on solid medium are circular with entire edges, smooth, convex and salmon pink, $0.5-1.0 \mathrm{~mm}$ in diameter after 34 days of incubation at $30{ }^{\circ} \mathrm{C}$. The optimal temperature for growth is $33{ }^{\circ} \mathrm{C}$. Growth occurs at 10 and $36{ }^{\circ} \mathrm{C}$, but not above $38{ }^{\circ} \mathrm{C}$. Optimal growth occurs in the presence of $1 \%$ $\mathrm{NaCl}$. Growth occurs in the presence of 0.5 and $6 \% \mathrm{NaCl}$, but not without $\mathrm{NaCl}$ or in the presence of $>7 \% \mathrm{NaCl}$. The optimal $\mathrm{pH}$ for growth is 7.3-8.3. Growth occurs at $\mathrm{pH} 6.9$ and 9.3, but not at $\mathrm{pH} 6.4$ or above $\mathrm{pH} 9.8$. Cytochrome oxidase-negative. Does not produce hydrogen sulfide or indole. Nitrate and nitrite are reduced. Positive for amylase and gelatinase. Negative for agarase, cellulase, chitinase, DNase, lipase (tri- $n$-butyrin), protease and xylanase. Hydrolyses aesculin, ONPG, and Tweens 20 and 40 , but not Tween 80 . Utilizes cellobiose, D-fructose, Dgalactose, lactose, D-mannose, L-rhamnose, trehalose and xylose, but not L-arabinose, D-glucose, glycerol, myoinositol, maltose, D-mannitol, raffinose, D-sorbitol, Lsorbose or sucrose. Susceptible to (per millilitre) ampicillin $(10 \mu \mathrm{g})$, chloramphenicol $(30 \mu \mathrm{g})$, erythromycin $(15 \mu \mathrm{g})$, penicillin $(10 \mu \mathrm{U})$, rifampicin $(5 \mu \mathrm{g})$, tetracycline $(30 \mu \mathrm{g})$ and vancomycin $(30 \mu \mathrm{g})$, but tolerant of gentamicin $(10 \mu \mathrm{g})$, kanamycin $(30 \mu \mathrm{g})$, nalidixic acid $(30 \mu \mathrm{g})$ and neomycin $(30 \mu \mathrm{g})$. The $\mathrm{G}+\mathrm{C}$ content of the genomic DNA of the type strain is $42.9 \mathrm{~mol} \%$ (determined by HPLC). The major isoprenoid quinone is MK-7. The dominant cellular fatty acids are iso- $\mathrm{C}_{15: 0}$ and anteiso- $\mathrm{C}_{15: 0}$.

The type strain, JAM-BA0501 ${ }^{\mathrm{T}}\left(=\mathrm{JCM} 15548^{\mathrm{T}}=\mathrm{NCIMB}\right.$ $\left.14482^{\mathrm{T}}\right)$, was isolated from a deep subseafloor sediment (247 $\mathrm{m}$ below the seafloor, $1180 \mathrm{~m}$ water depth) off the Shimokita Peninsula, Japan.

\section{Acknowledgements}

We thank Mr Katsuyuki Uematsu for assistance in preparing electron micrographs. We are very grateful to the shipboard scientists, technicians, drilling engineers and crew of the research vessel Chikyu for their help with sample collection.

\section{References}

Bachmann, B. J. (1955). Studies on Cytophaga fermentans, n.sp., a facultatively anaerobic lower myxobacterium. J Gen Microbiol 13, 541-551.

Barrow, G. I. \& Feltham, R. K. A. (editors) (1993). Cowan and Steel's Manual for the Identification of Medical Bacteria, 3rd edn. Cambridge: Cambridge University Press.

Denger, K., Warthmann, R., Ludwig, W. \& Schink, B. (2002). Anaerophaga thermohalophila gen. nov., sp. nov., a moderately thermohalophilic, strictly anaerobic fermentative bacterium. Int $\mathrm{J}$ Syst Evol Microbiol 52, 173-178.

Felsenstein, J. (1981). Evolutionary trees from DNA sequences: a maximum likelihood approach. J Mol Evol 17, 368-376.

Holt, J. G., Krieg, N. R., Sneath, P. H. A., Staley, J. T. \& Williams, S. T. (editors) (1994). Bergey's Manual of Determinative Bacteriology, 9th edn. Baltimore: Williams and Wilkins. 
Kobayashi, T., Koide, O., Mori, K., Shimamura, S., Matsuura, T., Miura, T., Takaki, Y., Morono, Y., Nunoura, T. \& other authors (2008). Phylogenetic and enzymatic diversity of deep subseafloor aerobic microorganisms in organics- and methane-rich sediments off Shimokita Peninsula. Extremophiles 12, 519-527.

Komagata, K. \& Suzuki, K. (1987). Lipid and cell-wall analysis in bacterial systematics. Methods Microbiol 19, 161-207.

Ludwig, W., Strunk, O., Westram, R., Richter, L., Meier, H., Yadhukumar, Buchner, A., Lai, T., Steppi, S. \& other authors (2004). ARB: a software environment for sequence data. Nucleic Acids Res 32, 1363-1371.

Ludwig, W., Euzeby, J. \& Whitman, W. B. (2008) Draft Taxonomic Outline of the Bacteroidetes, Planctomycetes, Chlamydiae, Spirochaetes, Fibrobacteres, Fusobacteria, Acidobacteria, Verrucomicrobia, Dictyoglomi, and Gemmatimonadetes. Published online: http://www.bergeys.org/ outlines/Bergeys_Vol_4_Outline.pdf

MIDI (1999). Sherlock, Microbial Identification System, Operating Manual, version 3.0. Newark, DE: MIDI, Inc.

Minnikin, D. E., O’Donnell, A. G., Goodfellow, M., Alderson, G., Athalye, M., Schaal, K. \& Parlett, J. H. (1984). An integrated procedure for extracting bacterial isoprenoid quinones and polar lipids. J Microbiol Methods 2, 233-241.

Miyazaki, M., Nogi, Y., Fujiwara, Y., Kawato, M., Kubokawa, K. \& Horikoshi, K. (2008). Neptunomonas japonica sp. nov., an Osedax japonicus symbiont-like bacterium isolated from sediment adjacent to sperm whale carcasses off Kagoshima, Japan. Int J Syst Evol Microbiol 58, 866-871.

Miyazaki, M., Nagano, Y., Fujiwara, Y., Hatada, Y. \& Nogi, Y. (2010). Aquimarina macrocephali sp. nov., isolated from sediment adjacent to sperm whale carcasses. Int J Syst Evol Microbiol 60, 2298-2302.

Na, H., Kim, S., Moon, E. Y. \& Chun, J. (2009). Marinifilum fragile gen. nov., sp. nov., isolated from tidal flat sediment. Int $J$ Syst Evol Microbiol 59, 2241-2246.
Nakagawa, Y. \& Yamasato, K. (1996). Emendation of the genus Cytophaga and transfer of Cytophaga agarovorans and Cytophaga salmonicolor to Marinilabilia gen. nov.: phylogenetic analysis of the Flavobacterium-Cytophaga complex. Int J Syst Bacteriol 46, 599-603.

Nogi, Y. \& Kato, C. (1999). Taxonomic studies of extremely barophilic bacteria isolated from the Mariana Trench and description of Moritella yayanosii sp. nov., a new barophilic bacterial isolate. Extremophiles 3, 71-77.

Nogi, Y., Kato, C. \& Horikoshi, K. (1998). Taxonomic studies of deepsea barophilic Shewanella strains and description of Shewanella violacea sp. nov. Arch Microbiol 170, 331-338.

Saito, H. \& Miura, K. I. (1963). Preparation of transforming deoxyribonucleic acid by phenol treatment. Biochim Biophys Acta 72, 619-629.

Saitou, N. \& Nei, M. (1987). The neighbor-joining method: a new method for reconstructing phylogenetic trees. Mol Biol Evol 4, 406-425.

Suzuki, M., Nakagawa, Y., Harayama, S. \& Yamamoto, S. (1999). Phylogenetic analysis of genus Marinilabilia and related bacteria based on the amino acid sequences of GyrB and emended description of Marinilabilia salmonicolor with Marinilabilia agarovorans as its subjective synonym. Int J Syst Bacteriol 49, 1551-1557.

Swofford, D. L. (1998). Phylogenetic analysis using parsimony (PAUP), version 4. Sunderland, MA: Sinauer Associates.

Tamaoka, J. \& Komagata, K. (1984). Determination of DNA base composition by reverse-phase high-performance liquid chromatography. FEMS Microbiol Lett 25, 125-128.

Veldkamp, H. (1961). A study of two marine agar-decomposing, facultatively anaerobic myxobacteria. J Gen Microbiol 26, 331-342.

Zhilina, T. N., Appel, R., Probian, C., Brossa, E. L., Harder, J., Widdel, F. \& Zavarzin, G. A. (2004). Alkaliflexus imshenetskii gen. nov. sp. nov., a new alkaliphilic gliding carbohydrate-fermenting bacterium with propionate formation from a soda lake. Arch Microbiol 182, 244-253. 